\title{
Liquid-chromatographic profiling of solutes in serum of uremic patients undergoing hemodialysis and chronic ambulatory peritoneal dialysis (CAPD); high concentrations of pseudouridine in CAPD patients
}

Citation for published version (APA):

Schoots, A. C., Gerlag, P. G. G., Mulder, A. W., Peeters, J. A. G., \& Cramers, C. A. M. G. (1988). Liquidchromatographic profiling of solutes in serum of uremic patients undergoing hemodialysis and chronic ambulatory peritoneal dialysis (CAPD); high concentrations of pseudouridine in CAPD patients. Clinical Chemistry, 34(1), 91-97.

Document status and date:

Published: 01/01/1988

\section{Document Version:}

Publisher's PDF, also known as Version of Record (includes final page, issue and volume numbers)

\section{Please check the document version of this publication:}

- A submitted manuscript is the version of the article upon submission and before peer-review. There can be important differences between the submitted version and the official published version of record. People interested in the research are advised to contact the author for the final version of the publication, or visit the $\mathrm{DOI}$ to the publisher's website.

- The final author version and the galley proof are versions of the publication after peer review.

- The final published version features the final layout of the paper including the volume, issue and page numbers.

Link to publication

\footnotetext{
General rights

- You may freely distribute the URL identifying the publication in the public portal. follow below link for the End User Agreement:

www.tue.nl/taverne

\author{
Take down policy \\ If you believe that this document breaches copyright please contact us at: \\ openaccess@tue.nl \\ providing details and we will investigate your claim.
}

Copyright and moral rights for the publications made accessible in the public portal are retained by the authors and/or other copyright owners and it is a condition of accessing publications that users recognise and abide by the legal requirements associated with these rights.

- Users may download and print one copy of any publication from the public portal for the purpose of private study or research.

- You may not further distribute the material or use it for any profit-making activity or commercial gain

If the publication is distributed under the terms of Article 25fa of the Dutch Copyright Act, indicated by the "Taverne" license above, please 


\title{
Liquid-Chromatographic Profiling of Solutes in Serum of Uremic Patients Undergoing Hemodialysis and Chronic Ambulatory Peritoneal Dialysis (CAPD); High Concentrations of Pseudouridine in CAPD Patients
}

\author{
A. C. Schoots, ${ }^{1}$ P. G. G. Gerlag, ${ }^{2}$ A. W. Mulder, ${ }^{3}$ J. A. G. Peeters, ${ }^{1}$ and C. A. M. G. Cramers'
}

Using "high performance" liquid chromatography, we studied non-protein-bound fractions and total concentrations of 18 solutes accumulating in sera from a group of 12 patients who were undergoing chronic ambulatory peritoneal dialysis (CAPD) and in predialysis sera from a group of 15 hemodialysis (HD) patients. We monitored longitudinal changes in solute concentrations for two patients with respect to change of therapy between HD and CAPD. The concentrations of pseudouridine $(P<0.001)$, uric acid $(P<0.001)$, and an unknown fluorescent solute, "UKF3" $(P<0.01)$, differed in sera of HD and CAPD patients. When standardized with respect to serum creatinine concentrations, the concentration of the transfer-RNA catabolite, pseudouridine, was significantly $(P<0.0001)$ higher in sera of CAPD patients than in $H D$ patients, suggesting an increase in turnover of transfer RNA. In stepwise linear discriminant analysis, the combination of pseudouridine and the probably biochemically related fluorescent unknown, UKF3, contributed most to the differentiation between sera from CAPD and HD patients.

Additional Keyphrases: transfer RNA - protein synthesis - protein binding - metabolic status - peritonitis - peritoneal permeability - discriminant analysis - ultrafiltration • uremia - fluorometry

During the last 10 years, chronic ambulatory peritoneal dialysis (CAPD) has more and more become an alternative to conventional hemodialysis (HD) in the treatment of endstage renal patients (1-3).4 Although recurrent peritonitis, with the accompanying decreased permeability of the peritoneal membrane, has limited the use of CAPD, this has become the method of choice for treating pediatric patients and (young) patients awaiting a kidney transplant. Problems of vascular access in hemodialysis, hypertension, and diabetes are also indications for treatment by CAPD. Homeostasis is better in CAPD-treated patients, because sudden fluctuations in fluid volume, electrolytes, and acid-base balance-as are seen in hemodialysis treatment-do not occur.

This, combined with the continuous removal of waste metabolites, leads to steady-state conditions in CAPD pa-

${ }^{1}$ Laboratory for Instrumental Analysis, SH 2.05, Faculty of Chemical Engineering, Eindhoven University of Technology, P.O. Box 513, $5600 \mathrm{MB}$ Eindhoven, The Netherlands.

2 Dept. of Internal Medicine and Dialysis Unit, St. Joseph Hospital, Eindhoven, The Netherlands.

3 Dept. of Internal Medicine and Dialysis Unit, Catharina Hospital, Eindhoven, The Netherlands.

"Nonstandard abbreviations: HPLC, "high-performance" liquid chromatography; HD, hemodialysis; CAPD, chronic ambulatory peritoneal dialysis; TCA, trichloroacetic acid; CREA, creatinine concentration in serum; PSI, pseudouridine concentration in serum; UKF, unknown fluorescent peak; and UK, unknown ultravioletabsorbing peak.

Received June 25, 1987; accepted October 21, 1987. tients. Generally, these patients exhibit higher hematocrit values than do $\mathrm{HD}$ patients (4). A controversial property ascribed to CAPD treatment is the supposedly more efficient removal of so-called neurotoxic middle molecules (5-8). In the square meter-hour hypothesis introduced by Babb et al. (5) in 1971, these poorly dialyzable solutes are thought to be responsible for neurological disorders in patients undergoing regular dialysis. In kinetic studies $(6-9)$ the ratio of predialysis solute concentration in $\mathrm{HD}$ to the steady-state concentration in CAPD plasma has higher values for solutes with higher molecular mass.

Hitherto, no evidence has been found that CAPD more efficiently removes those solutes that cause neurological symptoms. To measure the differences in solute concentrations in sera of patients treated with CAPD or with HD, we have used a screening method based on "high-performance" liquid chromatography (HPLC), as described previously (10).

\section{Materials and Methods}

Patients and Sera

Blood was sampled from 15 patients on $\mathrm{HD}$ treatment and 12 patients on CAPD. For hemodialysis we used Disscap 160 dialyzers (Cuprophan, Hospal, Meyzieu, France), a blood flow of $300 \mathrm{~mL} / \mathrm{min}$, and a dialysate flow of $500 \mathrm{~mL} / \mathrm{min}$. CAPD was performed with four 2-L exchanges within $24 \mathrm{~h}$. HD samples were taken before dialysis. CAPD patients were sampled in the outpatient department, more or less randomly during their daily routine bag exchange. Table 1 summarizes patient characteristics.

None of the CAPD patients had symptoms of peritonitis. The two patients changing the mode of therapy volunteered to do so; they had no clinical indication, such as peritonitis or problems with vascular access. Although the group of CAPD patients had been receiving (any) dialysis treatment for a shorter time, we found no significant difference in residual creatinine clearance between this group and the $\mathrm{HD}$ group. All patients were treated at least for three months with the method specified.

\section{Procedures}

Protein binding. Protein binding was measured by ultrafiltration through "Centrifree" ultrafiltration units (Amicon Corp., Danvers, MA). We subjected 1-mL aliquots of serum to ultrafiltration by centrifugation in the units, at $22^{\circ} \mathrm{C}$, at an angle of $30^{\circ}$, and at $1900 \times \mathrm{g}$, then determined the "free" (i.e., not protein bound) fractions of the solutes in the filtrate. To measure the total concentrations (i.e., bound and nonbound), we precipitated proteins by adding $50 \mu \mathrm{L}$ of a $100 \mathrm{~g} / \mathrm{L}$ solution of trichloroacetic acid (TCA) to $1 \mathrm{~mL}$ of serum, after treatment by ultrasonication. Then we centrifuged and ultrafiltered the samples, as described for the determination of free fractions. All Centrifree filtrates were analyzed by HPLC, after addition of an internal standard, 
Table 1. Some Characteristics of the Groups of Patients Studled

\begin{tabular}{|c|c|c|c|c|c|c|}
\hline \multirow[b]{2}{*}{ Variable } & \multicolumn{3}{|c|}{ CAPD $(n=12)$} & \multicolumn{3}{|c|}{ HD $(n=15)$} \\
\hline & $\bar{x}$ & SD & Range & $\bar{x}$ & SD & Range \\
\hline $\begin{array}{l}\text { RCC, } \mathrm{mL} / \mathrm{min}{ }^{*} \\
\text { Albumin, g/L } \\
\text { TTOD, months } \\
\text { Age, y } \\
\text { Sex ratio, F/M }\end{array}$ & $\begin{array}{c}2.3 \\
32.1 \\
9 \\
48 \\
3 / 9\end{array}$ & $\begin{array}{l}2.2 \\
5.4 \\
8 \\
17\end{array}$ & $\begin{array}{c}0-7.0 \\
20.6-38.2 \\
3-25 \\
18-67\end{array}$ & $\begin{array}{l}1.7 \\
34.0 \\
46^{c} \\
60 \\
9 / 6\end{array}$ & $\begin{array}{l}2.0 \\
3.4 \\
40 \\
10\end{array}$ & $\begin{array}{c}0-6.5 \\
30.1-40.9 \\
6-146 \\
37-72\end{array}$ \\
\hline
\end{tabular}

naphthalenesulfonic acid. We checked for any decomposition of uremic solutes caused by the added TCA and found the following losses, which we took into account in the calculations: pseudouridine $3.6 \%$, tyrosine $3.9 \%$, indoxyl sulfate $6.7 \%$, an unknown fluorescent peak UKF7A (see Figure 1 below) $10 \%$, and indole-3-acetic acid $10 \%$. Concentrations of all solutes in subsequent ultrafiltrates (collected at 20-min intervals) were constant, indicating that protein binding was maintained at equilibrium during ultrafiltration. This was not completely true for tryptophan and indoxyl sulfate, however, the concentrations of which increased slightly during ultrafiltration. For these solutes, we used the values obtained by extrapolation to zero ultrafiltration time. Protein binding (PBL, \%) was calculated as follows:

$$
\text { PBL, \% }=\left[1-\left(C_{f} / C_{t}\right)\right] \cdot 100
$$

where $C_{f}$ is the concentration of free solute, and $C_{t}$ is the total concentration.

HPLC. HPLC analysis was performed as described previously (10). We used a $4.6 \mathrm{~mm}$ (i.d.) $\times 25 \mathrm{~cm}$ Ultrasphere Octyl ( $\mathrm{C}_{8}$-modified silica) column, packed with 5 - $\mu \mathrm{m}$ (average diameter) particles, in conjunction with a $2 \mathrm{~mm}$ (i.d.) $\times$ $3 \mathrm{~cm}$ Ultrasphere Octyl guard column, packed with $10-\mu \mathrm{m}$ particles.

The solvent gradient was linear from ammonium formate buffer ( $50 \mathrm{mmol} / \mathrm{L}, \mathrm{pH} \mathrm{4}$ ) to methanol/buffer (60/40 by vol) within $45 \mathrm{~min}$. The flow rate was $1 \mathrm{~mL} / \mathrm{min}$.

The temperature of the solvent and separation columns was kept at $25^{\circ} \mathrm{C}$ by means of a thermostated bath and column water jacket. The chromatograph consisted of a Model 421 controller, two Model 100A double-piston pumps, a Model 160 fixed-wavelength ultraviolet-absorbance detector (wavelength $254 \mathrm{~nm}$, range $0.05 A$ full scale), and a Model 500 autosampler (all from Beckman Instruments, Berkeley, CA). For fluorescence detection we applied excitation at $280 \mathrm{~nm}$ and measured emission at $340 \mathrm{~nm}$ in a Model RF530 double monochromator fluorescence detector (Shimadzu, Tokyo, Japan).

Gas chromatography/mass spectrometry. For gas chromatography/mass spectrometry analysis we used a Model HP 5970A mass-selective detector coupled to an HP 5790A gas chromatograph (both from Hewlett Packard, Avondale, PA), equipped with a 40-m CPSil5 capillary column (Chrompack, Middelburg, The Netherlands).

The fraction corresponding to HPLC peak 2 (Figure 1) was isolated by repeated HPLC separation and coliection, was lyophilized, then derivatized with bis(trimethylsilyl)trifluoroacetamide (Pierce Chemical Co., Rockford, IL), and injected into the gas chromatograph through a fallingneedle solids injector.

Data acquisition, handling, and statistics. We used Model $761 S$ data interface and Model 2600 chromatography software (both from Nelson Analytical, Cupertino, CA), with an
IBM PC/XT computer. Chromatographic data were read in SAS datafiles, and subsequently analyzed with SAS statistical procedures NPAR1WAY, REG, and STEPDISC for the nonparametric Wilcoxon's test, regression analysis, and stepwise discriminant analysis, respectively (11). With STEPDISC, significance levels were 0.05 .

\section{Results}

The present study was divided into two parts. First, we analyzed and compared the concentrations of accumulated solutes in blood of two groups of patients, on CAPD $(n=12)$ and HD $(n=15)$. Second, we also determined the concentrations longitudinally in two patients changing therapy: one from CAPD to $\mathrm{HD}$ and the other vice versa. Characteristic HPLC profiles of the solutes are presented in Figure 1, both as absorbance and fluorescence traces. The unknown peak previously designated as UK6 (10) was identified by us by mass spectrometry as $p$-hydroxyhippuric acid.

Mass-spectrometric investigation also showed that the peak previously identified tentatively as uracil (10) is identical to pseudouridine (PSI). A mass spectrum of the trimethylsilyl derivative of the silylated HPLC peak 2 (Figure 2) was found to be identical to the mass spectrum of a trimethylsilyl derivative of PSI standard. The retention times for the isolated HPLC peak 2 and the PSI standard, both by HPLC (underivatized, co-injected) and by gas chromatography (derivatized), were identical. A more detailed description of this identification will be published elsewhere. The differences between the HPLC profiles shown in Figure 1 will be discussed below.

\section{Comparing the CAPD and the HD Patients}

The free (non-protein-bound) fractions and the total concentrations of the solutes under study are summarized in Tables 2 and 3. The data for the HD group were measured before dialysis. Obviously, comparing these blood concentrations is not very informative because the HD group is sampled in a worst-case condition with respect to the high predialysis blood concentrations. Therefore, for statistical analysis, all concentrations in the individual samples were standardized with respect to the corresponding creatinine concentrations:

$$
\mathrm{C}_{\mathrm{i}, \mathrm{st}}=\mathrm{C}_{\mathrm{i}} \cdot 1000 / \mathrm{CREA}
$$

where $C_{i}$ is concentration of component $i$, CREA is the corresponding creatinine concentration (in $\mu \mathrm{mol} / \mathrm{L}$ ), and $\mathrm{C}_{\mathrm{i} \text {, st }}$ is the "standardized" concentration. Creatinine was taken as the reference because it is more "constant" than urea, and because it is widely used as a marker in clinical practice. For the sake of unambiguity, we report the original (nonstandardized) concentrations in Tables 2 and 3. However, we applied Wilcoxon's test to both the nonstandardized and the standardized data. 

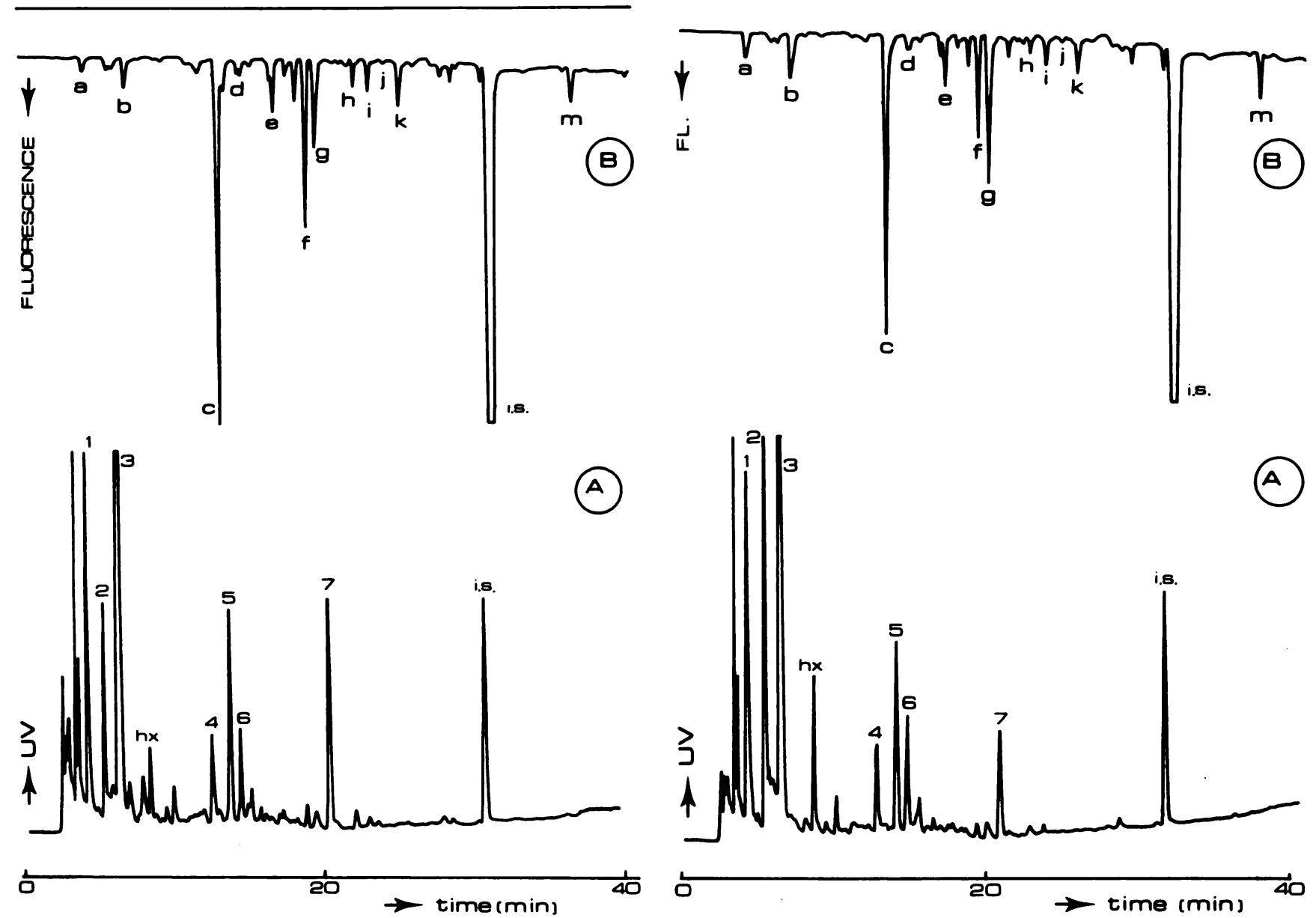

Fig. 1. HPLC-analysis of ultrafiltrated senum from patient $R$ when treated by hemodialysis (left), and two months later by CAPD (right)

(A) abeorbence at $254 \mathrm{~nm}$, (B) fluoreecence (280 nm excitation, $340 \mathrm{~nm}$ emission). The fluoreecence trace was attenuated to keep solute peak UKF3 on-8cale for comparison. Peek identification: 1, creatinine; 2, pseudouridine; 3, uric acid; hx, hypoxanthine; 4 and 5, unknown solutes UK4 and UK5; 6, phychoxyhippuric acid; 7, hippuric acid; a, unknown UKF1; b, tyrosine; $a$, unknown UKF3; $d$, unknown UKF4; $\theta$, unknown UKF5; $f$, indoxyl sulfate; $g$, tryptophan; $h$, unknown UKF6; $i$, unknown UKF7A; $j$, unknown UKF7; $k$, unknown UKF8; $m$, 3-indoloecetic acid

The standardized blood concentration of PSI is significantly higher $(P<0.0001)$ in the CAPD group than in the HD group, as is also true for UKF5 $(P<0.025)$ (Table 2). The standardized concentrations of PSI, calculated from the original data by using equation 1, are 76.3 and $38.7 \mathrm{mmol} /$ mol creatinine for CAPD and HD patients, respectively. Although average concentrations of a number of solutes such as hippuric acid and $p$-hydroxyhippuric acid appear to differ, this difference was not significant for these numbers of patients and the observed among-patient variance.

For none of the solutes was protein binding significantly different between the HD and CAPD groups (Table 4), by bivariate statistical analysis.

To study the differences in the profiles by considering the relation of the solutes one to the other, we used a multivariate approach, stepwise discriminant analysis (11). By stepwise selection both for free and total concentrations of the solutes at a significance level of $P=0.05$, only the variables PSI and unknown fluorescent compound UKF3 were selected. This means that the combination of these two variables contributed most to distinguishing the $\mathrm{HD}$ and CAPD groups; moreover, the influence of the combination was more than that of PSI alone, as was found by bivariate analysis of the standardized concentrations. Further analysis of the data showed that the serum concentrations of PSI and UKF3 were significantly correlated; in the $15 \mathrm{HD}$ patients $r=0.79(P<0.0005)$, and in the 12 CAPD patients $r=0.67(P<0.01)$ by Spearman rank correlation analysis. The groups separation by these two variables is illustrated in the scatter plot of Figure 3. The separate regression lines through the CAPD and HD data points have significantly different slopes $(\alpha=0.005)$, possibly pointing to a biochemical or structural relationship of the two solutes.

A further indication for this relationship was found during experiments on selective isolation of PSI. Nucleosides (e.g., PSI) are known to be extracted selectively by solid-phase extraction on boronate gel (12). Performing this procedure, we extracted not only PSI, but also UKF3, with approximately equal recovery. This supports the suggestion that UKF3 is a fluorescent nucleoside, a carbohydrate, a glucuronide, or some solute with a cis-diol group. Moreover, the solute is present abundantly in normal urine, but has not hitherto been identified decisively.

\section{Effects of Changing Therapy}

We monitored the concentrations of the uremic solutes in blood of two patients who were changing therapy. One patient $(\mathrm{K})$ volunteered to go from HD to CAPD therapy, and the other (R) changed therapy from CAPD to HD for reasons of lifestyle. Blood was sampled from both patients 


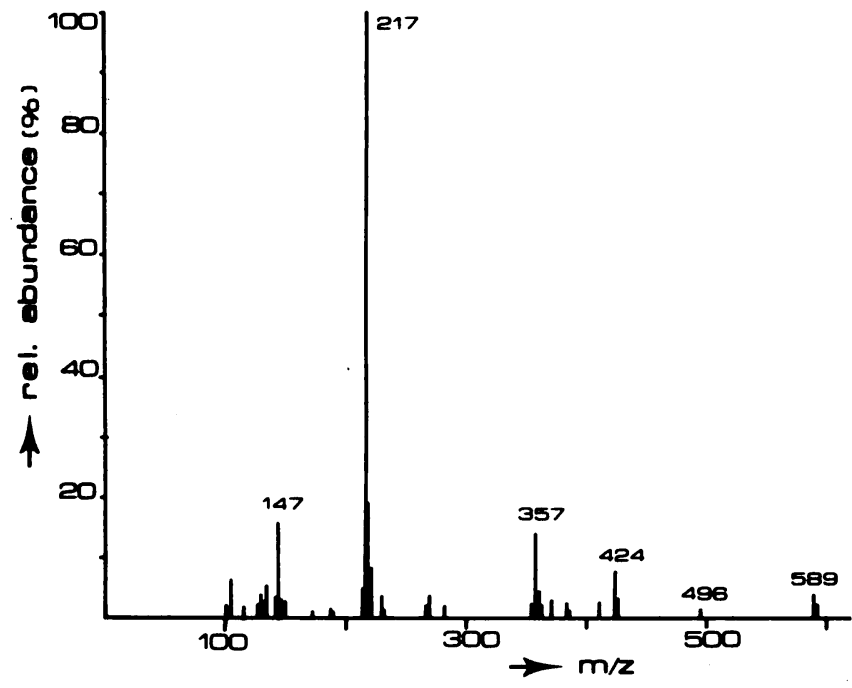

Fig. 2. Electron impact mass spectrum of trimethylsilylated, isolated HPLC peak 2 (see Fig. 1), which is identical to that of a similarty derivatized pseudouridine standard one month before the changeover, during the equilibration period, and then for another several weeks. Representative HPLC profiles for the HD and CAPD periods in one patient are shown in Figure 1.

In accordance with the data on the patients shown above, the most striking and significant change was the high PSI/CREA ratio in the CAPD intervals of both patients. In addition, the UKF3/PSI ratio changed even more signifcantly, as illustrated in Figure 4 for patient K. A similar but opposite change was seen in patient $\mathbf{R}$.

On the other hand, the hippuric acid concentration in patient $R$ decreased significantly with onset of CAPD treatment (Figure 5), whereas the reverse was not observed for patient $\mathrm{K}$, changing over from CAPD to $\mathrm{HD}$. In both patients the concentration of indoxyl sulfate, a tryptophan metabolite formed by intestinal bacteria, and the indoxyl sulfate/tryptophan ratio were significantly lower in the CAPD period. These results are summarized in Table 5.

\section{Discussion}

The most striking difference between HD and CAPD sera demonstrated in the HPLC profiles centers around pseu-

Table 2. "Free" Concentrations" of Bound and Nonbound Solutes in CAPD and HD Patients

\begin{tabular}{|c|c|c|c|c|c|c|}
\hline \multirow[b]{2}{*}{ Solute } & \multicolumn{3}{|c|}{$\operatorname{CAPD}(n=12)$} & \multicolumn{3}{|c|}{ HD $(n=15)$} \\
\hline & $\bar{x}$ & SD & Range & $\bar{x}$ & SD & Range \\
\hline $\begin{array}{l}\text { Creatinine } \\
\text { Pseudouridine } \\
\text { Uric acid } \\
\text { UK4 } \\
\text { UK5 } \\
\text { p-OH-hippuric acid } \\
\text { Hippuric acid } \\
\text { UKF1 } \\
\text { Tyrosine } \\
\text { UKF3 } \\
\text { UKF5' } \\
\text { Indoxyl sulfate } \\
\text { Tryptophan } \\
\text { UKF6 } \\
\text { UKF7A } \\
\text { UKF7 } \\
\text { UKF8 } \\
\text { 3-Indoleacetic acid }\end{array}$ & $\begin{array}{c}1248 \\
94.9 \\
479.5 \\
0.56 \\
1.33 \\
17.3 \\
208.0 \\
555 \\
75.4 \\
6368 \\
1859 \\
16.4 \\
10.7 \\
703 \\
2.5 \\
332 \\
3662 \\
2.6\end{array}$ & $\begin{array}{c}199 \\
40.0 \\
75.7 \\
0.43 \\
0.49 \\
11.9 \\
142.7 \\
456 \\
29.1 \\
1682 \\
965 \\
13.9 \\
3.2 \\
527 \\
1.3 \\
337 \\
2826 \\
0.8\end{array}$ & $\begin{array}{c}757-1511 \\
49.8-170.5 \\
339.9-564.3 \\
0.08-1.29 \\
0.70-2.23 \\
4.3-37.1 \\
36.7-490.8 \\
153-1812 \\
41.4-138.5 \\
4050-9756 \\
734-3309 \\
4.0-44.5 \\
5.9-16.1 \\
152-1640 \\
0.9-4.9 \\
92-1305 \\
1079-9125 \\
1.6-4.4\end{array}$ & $\begin{array}{c}1469 \\
55.9^{c . d} \\
630.2^{c} \\
0.46 \\
1.31 \\
22.5 \\
295.2 \\
514 \\
75.2 \\
8795^{\circ} \\
1276^{\prime} \\
11.8 \\
11.9 \\
536 \\
2.2 \\
333 \\
4473 \\
2.8\end{array}$ & $\begin{array}{c}330 \\
14.4 \\
144.2 \\
0.31 \\
0.61 \\
16.1 \\
241.8 \\
329 \\
19.0 \\
3401 \\
681 \\
7.7 \\
3.7 \\
452 \\
0.8 \\
192 \\
4064 \\
2.0\end{array}$ & $\begin{array}{c}960-2112 \\
41.7-83.8 \\
455.2-1057.7 \\
0.07-1.00 \\
0.55-2.62 \\
4.1-63.2 \\
35.8-893.8 \\
43-1223 \\
40.2-116.7 \\
2982-14761 \\
640-2879 \\
1.7-24.4 \\
5.9-18.4 \\
75-1926 \\
0.7-3.5 \\
68-828 \\
559-16169 \\
0.6-7.2\end{array}$ \\
\hline
\end{tabular}

${ }^{\circ} \mu \mathrm{mol} / \mathrm{L}$ unless indicated otherwise. ${ }^{\circ}$ Arbitrary units, used for unknown solutes. ${ }^{-1}$ Significantly different from CAPD values (by Wilcoxon's test) at: ${ }^{c} \boldsymbol{P}<0.001$, ${ }^{\circ} P<0.0001, \bullet P<0.01, ' P<0.025$. c. - Significance of original data; ${ }^{\alpha, ~ ' S i g n i f i c a n c e ~ a f t e r ~ s t a n d a r d i z a t i o n ~ i n ~ t e r m s ~ o f ~ s e r u m ~ c r e a t i n i n e ~ c o n c e n t r a t i o n . ~ A l l ~ o t h e r ~}$ comparisons not significant $(P \geq 0.05)$.

Table 3. Total Concentrations ${ }^{*}$ of Bound Solutes in CAPD and HD Patients' Sora

\begin{tabular}{|c|c|c|c|c|c|c|}
\hline \multirow[b]{2}{*}{ Solute } & \multicolumn{3}{|c|}{ CAPD $n=12$} & \multicolumn{3}{|c|}{ HD $n=15$} \\
\hline & $\bar{x}$ & so & Range & $\bar{x}$ & so & Range \\
\hline $\begin{array}{l}\text { UK5 } \\
\text { p-OH-hippuric acid } \\
\text { Hippuric acid } \\
\text { UKF1' } \\
\text { Indoxyl sulfate } \\
\text { Tryptophan } \\
\text { UKF6 } \\
\text { UKF7A } \\
\text { UKF7 } \\
\text { UKF8 } \\
\text { 3-Indoleacetic acid }\end{array}$ & $\begin{array}{c}1.45 \\
19.4 \\
307.0 \\
706 \\
96.7 \\
27.4 \\
2687 \\
2.7 \\
509 \\
3891 \\
5.6\end{array}$ & $\begin{array}{c}0.49 \\
12.8 \\
184.0 \\
573 \\
52.1 \\
9.2 \\
1448 \\
1.3 \\
316 \\
2875 \\
2.7\end{array}$ & $\begin{array}{c}0.69-2.23 \\
5.3-39.6 \\
71.3-686.5 \\
161-2271 \\
6.3-168.7 \\
8.5-43.9 \\
160-4517 \\
1.1-4.7 \\
140-1140 \\
1167-9575 \\
2.8-12.8\end{array}$ & $\begin{array}{c}1.45 \\
27.4 \\
432.4 \\
681 \\
94.0 \\
30.7 \\
2217 \\
2.3 \\
754 \\
4939 \\
8.7^{c}\end{array}$ & $\begin{array}{c}0.63 \\
16.2 \\
287.5 \\
407 \\
44.3 \\
8.1 \\
1108 \\
0.8 \\
464 \\
4216 \\
5.1\end{array}$ & $\begin{array}{c}0.57-2.70 \\
4.8-66.4 \\
78.7-1043.8 \\
56-1540 \\
2.3-152.3 \\
20.5-46.1 \\
228-3921 \\
0.6-3.6 \\
124-1794 \\
1313-17015 \\
3.4-22.1\end{array}$ \\
\hline
\end{tabular}


Table 4. Protein Binding of Uremic Solutes in CAPD and HD Patient's Sera

Protein binding, $\%$

\begin{tabular}{|c|c|c|c|c|}
\hline \multirow[b]{3}{*}{ Solute } & \\
\hline & \multicolumn{2}{|c|}{ CAPD $(n=12)$} & \multicolumn{2}{|c|}{ HD $(n=15)^{\circ}$} \\
\hline & $\bar{x}$ & SD & $\bar{x}$ & SD \\
\hline Creatinine & - $^{b}$ & - & - & - \\
\hline Pseudouridine & - & 一 & - & 一 \\
\hline UK5 & 7 & 11 & 11 & 7 \\
\hline p-OH-hippuric acid & 14 & 6 & 15 & 8 \\
\hline Hippuric acid & 36 & 8 & 38 & 8 \\
\hline UKF1 & 22 & 4 & 25 & 7 \\
\hline Tyrosine & 一 & - & - & 一 \\
\hline UKF3 & - & - & 一 & 一 \\
\hline UKF5 & - & - & $\bar{n}$ & - \\
\hline Indoxyl sulfate & 87 & 8 & 90 & 5 \\
\hline Tryptophan & 63 & 14 & 61 & 12 \\
\hline UKF6 & 79 & 9 & 74 & 18 \\
\hline UKF7A & 18 & 8 & 12 & 10 \\
\hline UKF7 & 42 & 25 & 55 & 14 \\
\hline UKF8 & 8 & 5 & 9 & 5 \\
\hline 3-Indol & 64 & 20 & 71 & 10 \\
\hline
\end{tabular}

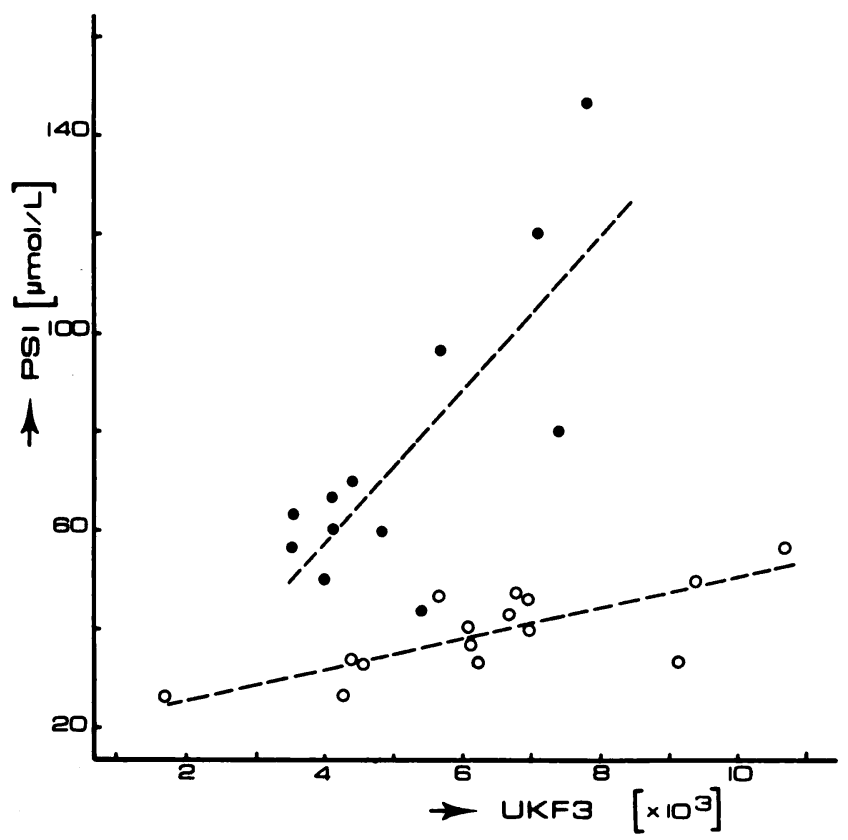

Fig. 3. Bivariate scatter plot of pseudouridine and UKF3 concentrations in sera of CAPD $(O)$ and $H D(O)$ patients UKF3 concentration expressed in arbitrary units

douridine, a modified nucleoside, and an unknown fluorescent solute UKF3, both of which also occur in normal urine. Pseudouridine is reportedly increased in uremia (13); however, the authors did not establish whether the higher concentrations originated from decreased excretion, increased generation, or both. Pseudouridine is a rare nucleoside found predominantly in transfer RNA (tRNA). It may be present also in messenger RNAs and ribosomal RNAs, but only in much lower proportions (14). Formation of PSI in tRNA takes place at the macromolecular level. Thus far there is no evidence that PSI phosphates are synthesized for use during transcription of tRNA in humans, although PSI monophosphate synthetases have been isolated from certain bacteria (15).

Therefore, PSI in normal urine and in uremic serum results predominantly from tRNA turnover. Because the

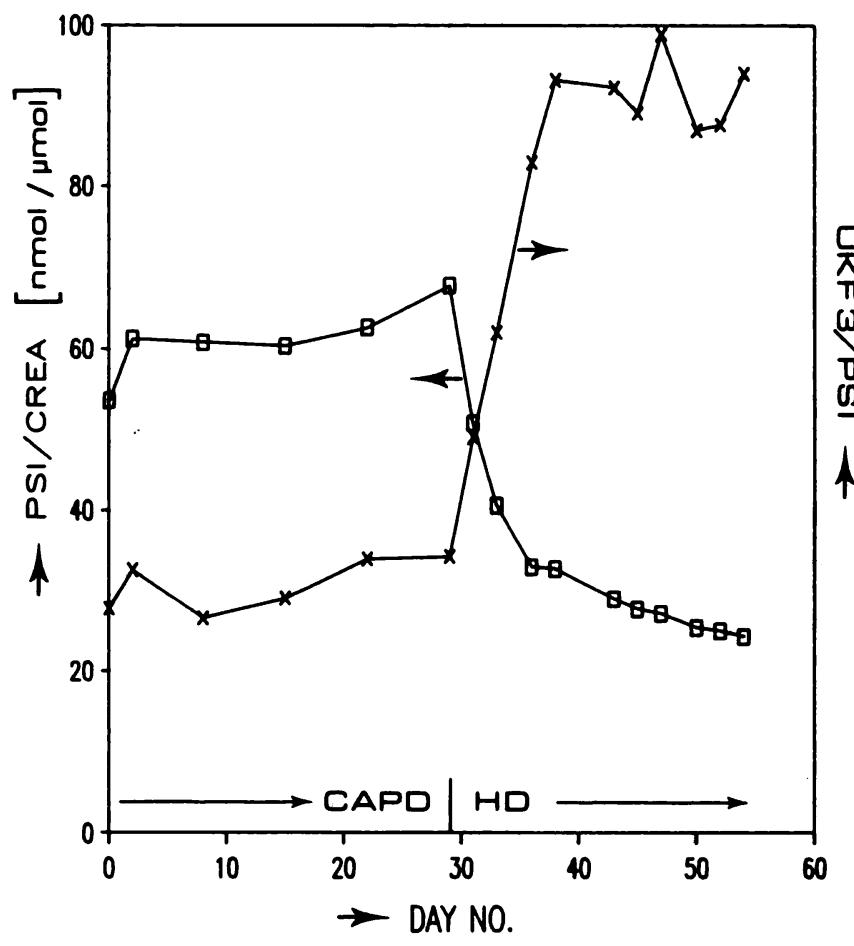

Fig. 4. Longitudinal plot of creatinine-standardized pseudouridine (PSV CREA $\square$ ), UKF3/PSI ratio $(X)$ in patient $K$, as treatment changed from CAPD to HD

UKF3/PSI ratio expressed in arbitrary units

PSI generated, unlike the regular nucleosides, is not phosphated and re-utilized and because it is chemically stable, PSI is excreted unmodified in the urine. Turnover of tRNA occurs during protein synthesis (16). tRNA plays a key role in protein synthesis, although it also has various other regulatory functions (17). High concentrations of urinary tRNA catabolites, such as PSI and methylated nucleosides, are found in patients with different forms of cancer or various other diseases (18).

It is unlikely that the high concentrations of PSI $\left(M_{\mathrm{r}} 244\right)$ we found in sera of CAPD patients are related to a less efficient removal of PSI than of creatinine $\left(M_{r} 113\right)$. Indeed, the reverse would be expected, because CAPD clears larger 


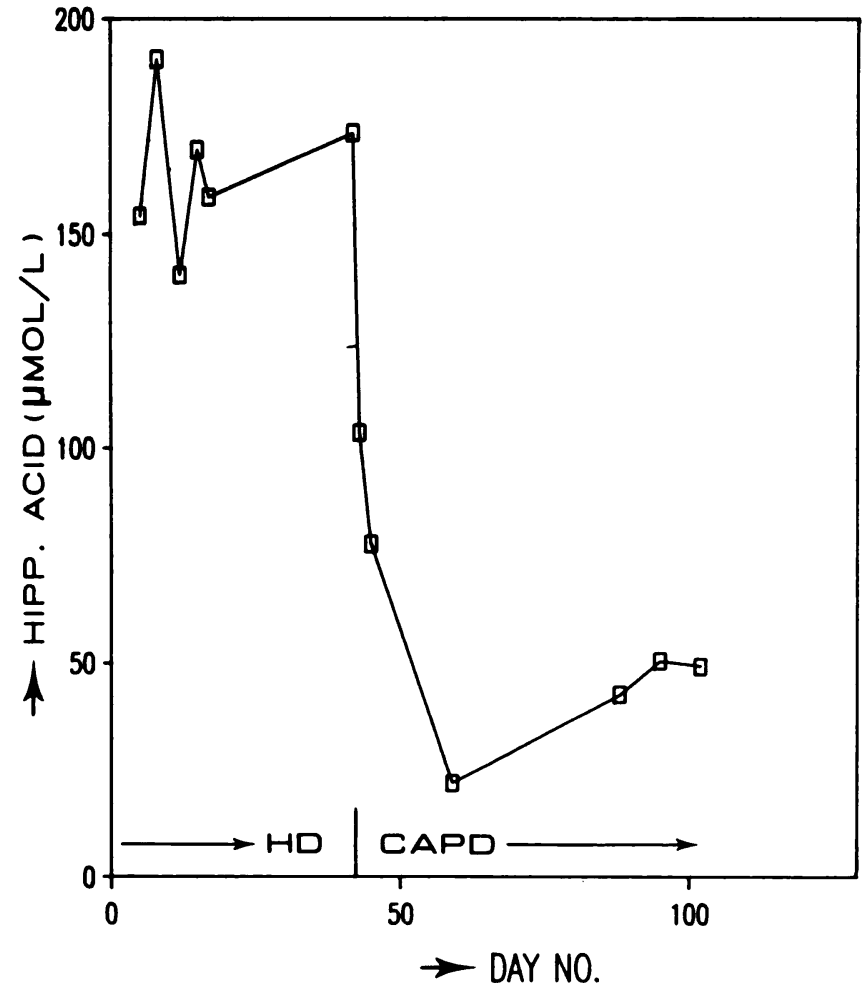

Fig. 5. Longitudinal plot of hippuric acid concentration in serum of patient $R$, as treatment changed from HD to CAPD

molecules more efficiently than does conventional hemodialysis when both methods show equivalent urea removal on a weekly basis $(6,9)$. However, there are no published data on the permeability of the peritoneal membrane to PSI.

In normal healthy adults the urinary PSI/CREA ratio is higher in women: 26.7 (SD = 4.E) vs $22.4(\mathrm{SD}=2.1)$ $\mathrm{mmol} / \mathrm{mol}$ in men (18). Although the patient groups studied here are asymmetric with respect to sex, this could not explain the difference because there were more females in the HD group, which had a lower mean value.

Two possible explanations of the high concentrations of PSI in serum from CAPD patients will be discussed here. First, asymptomatic, non-clinical peritonitis accompanied by cell death occurs in all CAPD patients, which could result in generation of PSI (19). Second, protein synthesis may be increased in these patients for various reasons. The possibly more efficient removal of certain unknown uremic toxins that might be inhibiting protein synthesis (20-22) and (or) the generally better homeostasis in CAPD may result in a more anabolic state (23). On the other hand, hemodialysis has been described as a catabolic process (24), the etiology of which is not yet clearly understood. Or protein synthesis may be induced by the combination of protein loss, via the peritoneal dialysate, and the availability of essential amino acids such as tryptophan (25), as a result of a more free diet. Although amino acid loss in peritoneal dialysis has been reported (26), these losses probably do not decrease the amino acid concentrations in plasma of stable patients who are eating well (27).

If the second explanation is valid, perhaps the serum PSI/CREA ratio can serve as an indicator of metabolic and nutritional status in dialyzed patients in addition to methods described elsewhere (27). Urinary PSI/CREA ratio has been proposed as an indicator of nutritional status in "healthy" persons, as an alternative to the determination of nitrogen balance, which is a very complicated procedure (16). Children demonstrate a strong age dependence of the excretion of creatinine-normalized RNA catabolites, reflecting age-dependent growth velocity (29). The PSI/CREA ratio in anabolic as well as catabolic processes was evaluated, and children with "failure to thrive" showed a marked depression of tRNA catabolites (30). Perhaps the higher serum PSI/CREA ratio in CAPD patients than in HD patients indicates a better noncatabolic status in CAPD. CAPD treatment reportedly is more beneficial to growth of children than is $\mathrm{HD}(31,32)$, probably as a result of better homeostasis and more free diet, despite the risk of undernutrition from treatment-induced anorexia.

It has been reported that urinary PSI excretion is positively related to protein intake (33). However, the PSI/ CREA ratio in normal individuals is closer to that in $\mathrm{HD}$ patients than to that in CAPD patients. Normal concentrations of PSI in serum have been reported as 2.48 (SD 0.13) $\mu \mathrm{mol} / \mathrm{L}$ (measured by HPLC) (34) and 1.72 (SD 0.77) $\mu \mathrm{mol} / \mathrm{L}$ (measured by RIA) (35). For a normal serum creatinine value of $80 \mu \mathrm{mol} / \mathrm{L}$, a normal serum PSI/CREA ratio would be $20-30 \mathrm{mmol} / \mathrm{mol}$, similar to the normal value for this ratio in urine. However, because healthy individuals ordinarily have neutral or positive nitrogen balance and nonrestricted protein intake, the foregoing seems to invalidate the suggestion that the high PSI/CREA ratio in CAPD is related to protein intake or protein synthesis, or both. Nonetheless, secondary effects associated with the derangement state of uremia are not unthinkable. No hard data were available on differences in diet between the groups of patients. To assess the metabolic state and (or) the influence of diet, careful clinical control of the different variables in a further study is indicated.

Less significant was our observation of the somewhat decreased concentrations of hippuric acid and $p$-hydroxyhippuric acid in CAPD patients than in HD patients. In a preceding pilot study involving seven patients on CAPD and three on $\mathrm{HD}$, a similar observation was made. In the present study, hippuric acid decreased very significantly with the onset of CAPD for a patient changing therapy.

Table 5. Significance of Differences in Various Analytes for HD Interval vs CAPD Interval

\begin{tabular}{|c|c|c|c|c|}
\hline Variable & $\begin{array}{l}\text { Pe for Patient K } \\
\text { (CAPD } \rightarrow \text { HD) }\end{array}$ & $\begin{array}{l}\text { Variable lower } \\
\text { in CAPD }\end{array}$ & $\begin{array}{l}P^{\circ} \text { for Patient } R \\
\text { (HD } \rightarrow \text { CAPD) }\end{array}$ & $\begin{array}{l}\text { Varlable lower } \\
\text { in CAPD }\end{array}$ \\
\hline $\begin{array}{l}\text { Pseudouridine/creatinine } \\
\text { Indoxyl sulfate } \\
\text { Indoxyl sulfate/tryptophan } \\
\text { UKF3/pseudouridine } \\
\text { Hippuric acid }\end{array}$ & $\begin{array}{l}<0.01 \\
<0.02 \\
<0.02 \\
<0.01 \\
\text { n.s. }\end{array}$ & $\begin{array}{l}\text { no } \\
\text { yes } \\
\text { yes } \\
\text { yes } \\
-\end{array}$ & $\begin{array}{l}<0.01 \\
<0.01 \\
<0.01 \\
<0.01 \\
<0.02\end{array}$ & $\begin{array}{l}\text { no } \\
\text { yes } \\
\text { yes } \\
\text { yes } \\
\text { yes }\end{array}$ \\
\hline
\end{tabular}

-By Wilcoxon's test for five samples each taken during the stable HD and the stable CAPD periods. Results for samples from the one-month equilibration period are not included. 
In conclusion: we found that pseudouridine concentrations in serum of CAPD patients are significantly higher than in HD patients. This difference is even more significant when concentrations are standardized to serum creatinine concentration. Further study is needed to answer the question whether low peritoneal membrane permeability, specific tRNA turnover, asymptomatic peritonitis accompanied by cell death, or another as-yet-unrecognized cellular process is the origin of the high pseudouridine concentrations in CAPD.

This study was supported in part by a grant from Travenol B. V., Utrecht, The Netherlands.

\section{References}

1. Boen ST. The evolution of peritoneal dialysis. In: Atkins RC, Thomson NM, Farrell PC. eds. Peritoneal dialysis, Edinburgh: Churchill Livingstone, 1981:3-12.

2. Moncrief JW, Popovich RP. Continuous ambulatory peritoneal dialysis best treatment for end-stage renal disease. Kidney Int 1985;28(suppl 17):23-5.

3. Popovich RP, Moncrief JW, Nolph KD, Gods AJ, Twardowski ZJ, Pyle WK. Continuous ambulatory peritoneal dialysis. Ann Intern Med 1978;88:449-56.

4. 7appacosta AR, Caro J, Erslev A. Normalization of hematocrit in patients with end-stage renal disease on continuous ambulatory peritoneal dialysis. The role of erythropoietin. Am $J$ Med 1982;72:53-7.

5. Babb A, Popovich R, Christopher T, Scribner B. The genesis of the square meter-hour hypothesis. Trans Am Soc Artif Intern Organs 1971;17:81-91.

6. Babb AL, Johansen PJ, Strand MJ, Tenckhoff H, Scribner BH. Bi-directional permeability of the human peritoneum to middle molecules. Proc Eur Dial Transpl Assoc 1973;10:247-57.

7. Schoots AC, Mikkers FEP, Claessens HA, De Smet R, Van Landschoot N, Ringoir SMG. Characterization of uremic "middle molecular" fractions by gas chromatography, mass spectrometry, isotachophoresis, and liquid chromatography. Clin Chem 1982;28:45-9.

8. Schoots A, Mikkers F, Cramers C, de Smet R, Ringoir S. Uremic toxins and the elusive middle molecules. Nephron 1984;38:1-8.

9. Nolph KD, Miller F, Rubin J, Popovich R. New directions in peritoneal dialysis concepts and applications. Kidney Int 1980;18(suppl 10):111-6.

10. Schoots AC, Homan HR, Gladdines MM, Cramers CA, de Smet $R$, Ringoir S. Screening of UV-absorbing solutes in uremic serum by reversed phase HPLC. Change of blood concentrations in different therapies. Clin Chim Acta 1985;146:37-51.

11. SAS user's guide. Statistics version, 5th ed. Cary, NC: SAS Institute Inc., 1985.

12. Gehrke CW, Kuo KC, David GE, Suits RD, Waalkes TP, Borek E. Quantitative high-performance liquid chromatography of nucleosides in biological materials. J Chromatogr 1978;150:455-76.

13. Asatoor AM. Retention of pseudouridine and 4-amino-5-imidazolecarboxamide in uraemia. Clin Chim Acta 1968;20:407-11.
14. Dirheimer G. Chemical nature, properties, location and physiological and pathological variations of modified nucleosides in tRNA's. In: Nass G, ed. Modified nucleosides and cancer. Berlin: Springer Verlag, 1983:15-46.

15. Heinrikson RL, Goldwasser E. Studies on the biosynthesis of 5ribosyluracil $5^{\prime}$-monophosphate in Tetrahymena pyriformis. J Biol Chem 1964;239:1177-87.

16. Schöch G, Heller-Schöch G, Müller J, Heddrich M, Grüttner R. Determination of RNA-metabolism as indicator of nutritional status. Klin Pädiatr 1982;194:317-9.

17. La Rossa R, Söll D. Other roles of tRNA. In: Altman S, ed. Transfer RNA. Cambridge, MA: MIT Press, 1978:136-67.

18. Sharma OK, Waalkes TP, Gehrke CW, Borek E. Applications of urinary nucleosides in cancer diagnosis and cancer management. Cancer Det Prev 1983;6:77-85.

19. Borek E, Baliga BS, Gehrke CW, et al. High turnover of RNA in tumor tissue. Cancer Res 1977;37:3362-6.

20. Delaporte C, Gros F, Anagnostopoulos T. Inhibitory effects of plasma dialysate on protein synthesis in vitro. Influence of dialysis and transplantation. Am J Clin Nutr 1980;33:1407-10.

21. Clayton EM, Seligson D, Seligson $H$. Inhibition of protein synthesis by $N$-methyl-2-pyridone-5-formamidoacetic acid and other compounds isolated from uremic patients. Yale $J$ Biol Med 1965;38:273-81.

22. Goubeaud G, Leber HW, Schott HH, Schütterle G. Middle molecules and haemoglobin synthesis. Proc Eur Dial Transpl Assoc 1977;13:371-6.

23. Randerson DH, Chapman GV, Farrell PC. Amino acid and dietary status in CAPD patients. In ref.1, pp 179-91.

24. Farrell PC, Hone PW. Dialysis-induced catabolism. Am J Clin Nutr 1980;33:1417-22.

25. Rothschild MA, Oratz M, Mongelli J, Fishman L, Schreiber SS. Amino acid regulation of albumin synthesis. J Nutr 1969;98:395403.

26. Berlyne GM, Lee HA, Giordano C, De Pascale C, Esposito R. Amino acid loss in peritoneal dialysis. Lancet 1967;i:1339-41.

27. Blumenkrantz MJ. Protein and nitrogen metabolism during CAPD: comparison with hemodialysis. In ref.1, pp 192-7.

28. Blumenkrantz MJ, Kopple JD, Gatman RA, et al. Methods for assessing nutritional status of patients with renal failure. Am J Clin Nutr 1980;33:1567-85.

29. Schöch G, Heller-Schöch G, Baisik H, Clemens P. Die Altersabhängigkeit der normalen und modifizierten Nucleobasen in Urin als Ausdruck der Wachstumsgeschwindigkeit. Monatsschr Kinderheilk 1981;129:29_33.

30. Schöch G, Leifer W, Grüttner R. Ausscheidung von Nucleinsäureabbauprodukten in Urin. Messmethodik und Bedeutung. Monatsschr Kinderheilk 1976;124:428-9.

31. Balfe JW. Metabolic effects of CAPD in the child. Perit Dial Bull 1983;3:21-3.

32. Nolph KD. Peritoneal dialysis. The Hague: Nijhoff, 1985:547.

33. Eisen AZ, Weissman S, Karon M. Pseudouridine metabolism. I. Isolation and the effect of diet on urinary excretion. $J$ Lab Clin Med 1962;59:620-9.

34. Russo T, Colonna A, Esposito F, Salvatore F, Cimino F. Detection and estimation of several modified nucleosides in serum of cancer patients. Ital $\mathrm{J}$ Biochem 1982;31:75-8.

35. Levine L, Waalkes TP, Stolbach L. Serum levels of $N^{2}, N^{2}$. dimethyl-guanosine and pseudouridine as determined by radioimmunoassay for patients with malignancy. J Natl Cancer Inst 1975;54:341-43. 